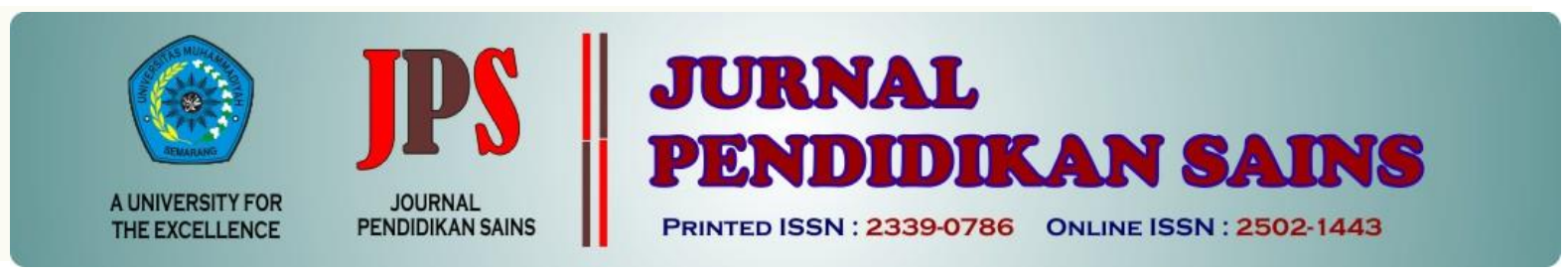

http://jurnal.unimus.ac.id/index.php/JPKIMIA

\title{
PENGEMBANGAN MODEL PEMBELAJARAN GETARAN BERBASIS VIDEO YOUTUBE UNTUK MENINGKATKAN PEMAHAMAN KONSEP MAHASISWA POLITEKNIK
}

\author{
Oleh: \\ I Gede Rasagama \\ Prodi Teknik Aeroneutika, Jurusan Teknik Mesin, Politeknik Negeri Bandung
}

\begin{tabular}{ll}
\hline \multicolumn{2}{l}{ Article history } \\
\hline Submission & $: 2020-06-27$ \\
Revised & $: 2020-06-29$ \\
Accepted & $: 2020-07-06$
\end{tabular}

Keyword:

Kata kunci: learning models, learning videos, understanding the concept of vibration.

\begin{abstract}
The research aims to find out: a video-based vibration learning model from http://youtube.com to improve understanding of concepts, their feasibility, strengths and weaknesses. Research using the $R \& D$ approach by Borg and Gall, in 4 stages including introduction, design, development, and validation. Research shows that the learning model consists of an introduction, core activities, and closing, which contains objectives, sequence of material, and discussion based on student questions; which is considered correct by experts, in the categories "within the scope of the concept" and "the truth of the concept"; perceived in the category "between good enough and good" and "between good and very good", respectively by students in trials I and II; strengths: the scope of the concept is comprehensive, easily accessed and repeated, saves lecturer power, and references 1 subtopic covering a variety of videos; and weaknesses: video 1 sub-topic in the form of file compilation, the majority of English language, and binding learning objectives.
\end{abstract}

\section{Pendahuluan}

Pendidikan bagi setiap bangsa merupakan salah satu bidang strategis yang selalu diperhatikan, dievaluasi, dikendalikan, dan ditingkatkan mutunya secara berkelanjutan sampai bangsa itu mampu bersaing dan unggul dari bangsa lain. Unggul di bidang pendidikan merupakan jaminan kuatnya bidang ekonomi suatu bangsa. Kemajuan bidang pendidikan suatu bangsa berimbas seperti efek domino, yaitu mampu memicu kemajuan bidang-bidang lainnya. Fokus pembangunan bangsa pada bidang pendidikan adalah salah satu cara dalam mempersiapkan sumber daya manusia dan menghadapi arus globalisasi, yang pada satu sisi dapat dipandang sebagai tantangan, namun

*Corresponding Author:

$\begin{array}{ll}\text { Nama } & \text { : I Gede Rasagama } \\ \text { Lembaga } & \text { : Politeknik Negeri Bandung } \\ \text { Email } & \text { : igesagama@ polban.ac.id }\end{array}$

disisi lain dapat dipandang sebagai hal yang menakutkan (Mustari, 2014).

Layanan sebuah institusi pendidikan dikatakan bermutu jika peserta didik telah memiliki kompetensi sesuai atau melebihi standar nasional pendidikan (Triwiyanto, 2013). Di era sekarang, sebuah keniscayaan jika proses layanan pendiddikan bermutu itu dijalankan tanpa melibatkan media pembelajaran. Menurut Wiratmojo dan Sasonohardjo, pemanfaatan media pembelajaran tersebut mampu membangkitkan rasa ingin tahu, minat, dan motivasi, mengarahkan pembelajaran dan menimbulkan efek psikologis peserta didik (Falahudin, 2014). Disamping itu pemanfaatannya juga sangat membantu 
efektivitas proses penyampaian pesan dan isi materi sesuai target kurikulum.

Video merupakan salah satu tipe media pembelajaran dengar dan pandang yang bisa dikondisikan interaktif. Mula-mula peserta didik dipancing, lalu merespon, dan akhirnya mengkontruksi isi materi sebagai pengetahuan di benaknya melalui umpan balik berupa pengajuan pertanyaan-pertanyaan konstruktif. Umpan balik ini menciptakan interaksi diantara peserta didik dengan peserta didik lain, dan peserta didik dengan pengajar (Izzudin, 2013.). Video dapat menjadi media refleksi pengajar guna mengevaluasi proses pembelajaran sebelumnya sehingga kedepan mampu mengubah cara mengelola kelas yang berimbas pada perbaikan motivasi belajar peserta didik (Yuliyanto, 2018.). Video juga dapat mengatasi keterbatasan jarak dan waktu, diulangi bila dibutuhkan, mengembangkan pendapat dan imajinasi peserta didik (Munadi, 2013), serta menurut Mell Silberman bahwa pembelajaran dengan video (visual) mampu meningkatkan ingatan dari $14 \%$ menjadi $38 \%$ dan perbaikan 200\% kosa kata peserta didik (Purwanti, 2015).

Http://youtube.com adalah sebuah situs web yang sarat dengan "berbagi video" dan pengguna dimungkinkan untuk mengunggah, menonton, dan berbagi video pembelajaran. Situs ini mudah diakses oleh siapa saja dan telah menyediakan media pembelajaran untuk berbagai bidang studi atau mata kuliah, termasuk fisika dasar, baik produk dari dalam maupun luar negeri. Untuk itu pemanfaatan video pembelajaran secara selektif dari situs ini sangat dianjurkan pada semua pengajar untuk melayani dan memajukan pendidikan fisika di Indonesia. Sejak diluncurkan sebagai situs web untuk berbagi video setiap hari di tahun 2005, youtube telah menjadi salah satu platform media digital paling kuat di dunia (Burgess, 2018.).

Getaran dibedakan atas tipe harmonis, teredam, dan terpaksa. Getaran harmonis merupakan gerak yang berlangsung periodik dan kontinu. Getaran harmonis terjadi karena bekerja gaya pemulih, dengan karakter mengikuti hukum Hooke. Dua gaya pemulih atau lebih bisa menimbulkan fenomena lisajous yang menarik sebagai bentuk penerapan konsep superposisi seperti diperlihatkan oleh osiloskop. Getaran teredam merupakan getaran harmonis yang mengalami gaya redaman. Gaya ini tergantung pada jenis medium peredam (tetapan gaya redam) dan kecepatan sistem bergetar.
Adanya kenyamanan karena usaha meminimalisasi goncangan pada semua alat tranportasi adalah aplikasi penting konsep getaran teredam kritis. Getaran terpaksa merupakan getaran teredam yang mengalami gaya luar periodik dan kontinu. Konsep getaran terpaksa menjadi penting karena mampu menjelaskan gejala resonansi atau getaran maha dahsyat dan sangat destruktif pada sebuah sistem seperti jembatan, gedung, kapal, dan pesawat (Giancoli, 2016.); (Young, 2016.).

Konsep merupakan istilah yang sengaja dirumuskan para pakar untuk kepentingan transfer ilmu. Pada suatu konsep melekat suatu pengertian tertentu. Mengajarkan konsep dengan mudah sehingga terjadi pemahaman yang benar pada diri peserta didik haruslah menjadi sebuah kesadaran bersama, khususnya diantara para pengajar. Menurut Brotosiswoyo, kesadaran ini termasuk 1 dari 7 tipe keterampilan generik yang harus terbentuk dalam diri peserta didik melalui pembelajaran sains-fisika (Rusli, 2011). Bahkan sangat diinginkan agar terjadi suatu tatanan ideal dimana pemahaman konsep peserta didik yang terbentuk, diharapkan tepat sama seperti pemahaman konsep fisikawan (Mustofa, 2016). Menurut Mastie \& Johson, pemahaman konsep terjadi jika peserta didik mampu mengenali (menyadari sesuatu hal pernah dijumpai), menjelaskan (menyampaikan sesuatu hal dengan memberi pernyataan-pernyataan dan uraian-uraian), dan menginterpretasi (menerapkan pengetahuan pada sesuatu hal secara tepat) masalah (Sariningsih, 2014). Pemahaman konsep ini termasuk salah satu produk pendidikan yang harus dikembangkan dalam pembelajaran fisika (Nurjamilah, 2017).

Kemudahan akses berbasis pada kekuatan-kekuatan yang melekat dari video pembelajaran getaran http://youtube.com terpilih sangat memungkinkan untuk dilakukan pengembangan model pembelajaran getaran berbasis video untuk meningkatkan pemahaman konsep getaran mahasiswa politeknik. Pemahaman konsep getaran oleh para mahasiswa politeknik secara benar sangatlah membantu para lulusan dalam memecahkan masalah superposisi, redaman kritis dan resonansi, yang mungkin kelak menjadi bidang profesi atau pekerjaannya. Penelitian ini bertujuan untuk mengetahui (i) model pembelajaran getaran berbasis video dari http://youtube.com untuk meningkatkan pemahaman konsep mahasiswa politeknik; (ii) kelayakan model pembelajaran getaran yang 
dikembangkan berdasarkan penilaian pakar dan penilaian mahasiswa politeknik; dan (iii) kekuatan dan kelemahan model pembelajaran yang dikembangkan sebagai rekomendasi bagi dosen politeknik yang ingin menerapkan model pembelajaran terkait dalam rangka meningkatkan mutu layanan pendidikan fisika di institusinya.

\section{Metode Penelitian}

Penelitian dilakukan di kota Bandung selama 5 bulan dari Juli sampai dengan November 2019. Subyek penelitian adalah mahasiswa kelas 1DEB DIII Program Studi Teknologi Perancangan Mekanik POLMAN Bandung, Kelas 1A dan Kelas 1B DIII Program Studi Teknik Aeroneutika Politeknik Negeri Bandung dan 1 orang pakar metode pembelajaran.

Metode penelitian memakai pendekatan R\&D dalam 4 tahapan sebagai hasil modifikasi metode R\&D oleh Borg dan Gall (Rasagama, 2011), meliputi: (i) studi pendahuluan yaitu melakukan analisis video pembelajaran dari website, analisis urutan konsep materi, analisis konsep, dan analisis indikator pemahaman konsep; (ii) perancangan yaitu menyusun model pembelajaran dan instrumen pendukungnya; (iii) pengembangan yaitu melakukan penilaian benar/salah dan permintaan saran terhadap model pembelajaran dan instrumen pendukung kepada seorang pakar metode pembelajaran fisika, melakukan ujicoba terbatas I model pembelajaran pada kelas eksperimen tanpa memakai kelas kontrol, dan merevisi model pembelajaran tahap I; dan (iv) validasi yaitu melakukan ujicoba terbatas II model pembelajaran pada kelas eksperimen dengan memakai kelas kontrol, dan merevisi model pembelajaran tahap II. Dalam ujiciba terbatas II dipakai pretest-posttest control group design dan ujicoba terbatas I dipakai one group pretest-posttest design.

Objek penelitian yang dikembangkan adalah model pembelajaran getaran berbasis video-youtube untuk meningkatkan pemahaman konsep mahasiswa politeknik, dengan didukung instrumen penelitian berupa video pembelajaran getaran dari website https://youtube.com, bahan ajar pokok bahasan getaran, dokumen urutan konsep materi, dokumen analisis konsep dan dokumen indikator pemahaman konsep, 7 item soal angket penilaian pakar, 25 item soal angket penilaian mahasiswa, 40 soal tes pilihan ganda plus 5 soal tes uraian untuk pemahaman konsep getaran, dan lembar observasi kegiatan ujicoba model pembelajaran penelitian.

Data angket pakar dianalisa untuk melihat hasil penilaian pakar perihal benar (B) atau salah (S) dari desain objek dan instrumen penelitian dalam 2 katagori yaitu: "dalam lingkup konsep (DLK)" dan "kebenaran konsep (KK)". Data angket pakar juga dianalisa untuk melihat saran pakar untuk perbaikan konten objek penelitian dan instrumen penelitian pendukung. Data angket penilaian mahasiswa dianalisa dengan membandingkan rerata skor perolehan dengan katagori skor referensi (skala Likert). Data tes pemahaman konsep mahasiswa dianalisa secara kuantitatif untuk mengetahui rerata skor gain ternormalisasi (NG) dari skor tes awal ke tes akhir baik untuk kegiatan ujicoba terbatas I maupun ujicoba terbatas II. Kualitas perbedaan rerata skor pemahaman konsep mahasiswa diantara kelas eksperimen dengan kelas kontrol (ujicoba terbatas II) maupun diantara tes awal dan tes akhir dari kelas eksperimen tanpa memakai kelas kontrol (ujicoba terbatas I), keduanya dianalisa dengan uji-statistika meliputi uji normalitas, uji homogenitas, dan uji-T atau ujiWilcoxon. Kekuatan dan kelemahan model pembelajaran penelitian diperoleh dengan menganalisa proses perumusan yaitu selama penerapan metode $\mathrm{R} \& \mathrm{D}$ terkait diterapkan.

\section{Hasil Penelitian dan Pembahasan}

Desain model pembelajaran getaran berbasis video-youtube untuk meningkatkan pemahaman konsep getaran didasari atas hasil observasi beberapa video pembelajaran getaran yang dapat diunduh dari http://youtube.com. Berdasarkan deskripsi konten website hasil seleksi yang berasal dari sejumlah video pembelajaran getaran maka ditetapkan 12 buah video pembelajaran getaran (6 video untuk getaran harmonis, 3 video untuk getaran teredam, dan 3 video untuk getaran terpaksa), dengan masing-masing video berdurasi antara 4 sampai dengan 21 menit. Hasil observasi secara detail terhadap setiap video pilihan, menuntun peneliti merumuskan desain model pembelajaran dan semua instrumen pendukung. Model pembelajaran adalah konsepsi prosedur sistematik berbasiskan teori berupa pengorganisasian pembelajaran demi mencapai tujuan pembelajaran itu sendiri. Model pembelajaran sangat terkait dengan penetapan dan pembuatan strategi, serta aktivitas peserta didik. Ciri utamanya, memuat sintaks dan bermuara pada asesmen komprehensif, baik 
untuk proses dan produk, baik untuk aspek kognitif, afektif, dan psikomotorik (Al-Tabany, 2017).

Bahan ajar pokok bahasan getaran merupakan resume konsep-konsep yang ada dalam materi pokok bahasan getaran baik getaran harmonis, getaran teredam, dan getaran paksa. Secara detail setiap konsep yang ada dalam video pembelajaran getaran pilihan disajikan dalam bahan ajar. Pemakaian bahan ajar berbasis konsep-konsep penting secara sitematis diharapkan mampu meningkatkan pemahaman konsep peserta didik. Ini selaras dengan hasil penelitian pengembangan buku ajar yang terintegrasi dengan proses saintifik tampak dapat menjadi suplemen pokok untuk membelajarkan keterampilan berpikir kritis peserta didik (Hidayat, 2018). Bahan ajar ini dibagikan ke setiap mahasiswa yang terlibat dalam penelitian baik kelas pada ujicoba terbatas I maupun ujicoba terbatas II. Bahan ajar ini merupakan media-tulis pembelajaran tambahan untuk membantu mahasiswa melaksanakan pemahaman semua konsep getaran. Disamping juga mahasiswa dapat memperoleh pemahaman konsep getaran dari video pembelajaran yang telah ditetapkan.

Urutan konsep materi getaran merupakan pemetaan konsep-konsep yang ada pada pokok bahasan getaran dan sub-sub pokok bahasan getaran. Kemunculan setiap konsep tampak terjadi secara berurutan dari konsep primer (lapisan utama) ke beberapa konsep sekunder (lapisan kedua). Dari setiap konsep sekunder tampak muncul lagi beberapa konsep tersier (lapisan ketiga) dan seterusnya. Melalui penyusunan instrumen tipe ini tampak seluruh konsep-konsep yang menyusun pokok bahasan getaran menjadi terintegrasi dan saling terkait satu sama lain sehingga dapat memberikan penguatan kepada mahasiswa dalam melakukan pemahaman konsep getaran. Instrumen ini dibagikan pada setiap mahasiswa baik yang terlibat pada kegiatan ujicoba terbatas I, maupun ujicoba terbatas II. Pemanfaatan fasilitator ini dapat memperkuat struktur kognitif awal peserta didik sebelum mengikuti pembelajaran yang sesungguhnya. Menurut Ausubel, kegiatan tipe ini termasuk pembelajaran bermakna, karena konsepsi baru dikaitkan dengan pra-konsep peserta didik (Dahar, 2011). Pembelajaran fisika melalui metode advance organizer berbasis peta konsep lebih baik dan efektif dalam menumbuhkan sikap ilmiah peserta didik dibanding metode konvensional (Nopiani, 2017).
Analisis konsep getaran merupakan kegiatan merinci karakteristik setiap konsep yang terkandung dalam pokok bahasan getaran. Berdasarkan kegiatan ini dapat diketahui bahwa setiap konsep tersebut memiliki label, definisi, atribut (kritis dan variabel), hirarki (superordinat, ko-ordinat, maupun sub-ordinat), dan jenis konsep. Kegiatan ini telah memberikan penguatan konsep yang sangat baik bagi peneliti maupun pengajar, sebelum mengajarkan konsep getaran di hadapan para mahasiswa. Analisis konsep yang dilakukan pengajar sebelum pembelajaran di kelas membangun sebuah struktur kgnitif berupa konsep dasar, yang menjadi asal-muasal setiap konsep dalam lingkup pokok bahasan. Pengajaran sebuah konsep kepada peserta didik harus selalu diawali dengan pengenalan konsep dasarnya, yang memuat perihal historisnya (Basuki, 2017).

Analisis indikator pemahaman konsep getaran dan soal pemahaman konsep getaran merupakan 2 instrumen penting untuk ketepatan target evaluasi berupa perolehan hasil belajar mahasiswa setelah mengikuti pembelajaran. Indikator pemahaman konsep menjadi bagian penting dari tujuan pembelajaran itu sendiri. Berdasarkan indikator-indikator tersebut, pembelajaran menjadi terkendali dalam pelaksanaannya. Analisis indikator pemahaman konsep bermuara pada dimensi sain (fisika) yang dievaluasi, meliputi dimensi makroskopik, mikroskopik, dan simbolik. Evaluasi ke-3nya secara simultan setelah pembelajaran merupakan evaluasi terhadap bentuk representasi diri setiap peserta didik ketika memahami suatu konsep atau model mental (Priyadi, 2018). Tentu saja model mental setiap bidang studi perlu diketahui oleh segenap stakeholder sebagai dasar pengambilan dan penetapan regulasi untuk kemajuan layanan pendidikan bagi setiap warga negara di Indonesia.

Dalam penelitian ini ditetapkan indikator pemahaman konsep mengikuti pendapat Mastie \& Johson, dimana indikator pemahaman konsep tersusun atas 3 bagian utama, yaitu kemampuan mengenal konsep, kemampuan menjelaskan konsep dan kemampuan menginterpretasi konsep (Sariningsih, 2014). Berdasarkan pada indikator-indikator pemahaman konsep yang telah disusun tersebut maka dirumuskan kisi dan soal pemahaman konsep getaran meliputi 40 soal tipe pilihan ganda dan 5 soal tipe uraian. Rincian ke-45 soal tersebut meliputi 15 
soal PG getaran harmonis, 10 soal PG getaran teredam, 10 soal PG getaran terpaksa, dan 5 soal uraian getaran harmonis. Semua soal terbagi dalam 3 katagori bobot soal yaitu 10 soal katagori mudah, 25 soal katagori sedang, dan 10 soal katagori sukar.

Kisi dan soal angket penilaian pakar metode pembelajaran merupakan 2 instrumen yang digunakan untuk merumuskan aspekaspek yang diukur dan soal-soal atau pertanyaan-pertanyaan dalam rangka menjaring penilaian benar atau salahnya konten model pembelajaran dan tipe-tipe instrumen lain yang telah didesain. Penilaian benar atau salah dari konten setiap tipe istrumen penelitian yang dimaksud adalah dalam katagori DLK dan KK. Dalam setiap tipe instrumen, pakar juga diberikan ruang untuk menulis saran untuk perbaikan jika diperlukan.

Kisi-kisi dan soal angket penilaian mahasiswa merupakan 2 instrumen untuk mengetahui penilaian mahasiswa perihal kelayakan (kualitas) model pembelajaran yang dikembangkan. Pengisiam angket dilaksanakan setelah mahasiswa mengikuti seluruh rangkaian pembelajaran meliputi tes awal, proses pembelajaran, dan tes akhir. Didesain 25 pertanyaan (soal) dalam 10 katagori untuk menjaring penilaian mahasiswa yaitu:

1. Tingkat penerimaan peserta didik terhadap sistimatika materi yang telah disajikan (2soal);

2. Tingkat penerimaan peserta didik terhadap metode pembelajaran yang dilaksanakan (3soal);

3. Tingkat kuriositas (minat dan rasa ingin tahu) peserta didik yang ditimbulkan oleh metode pembelajaran (2soal);

4. Tingkat motivasi diri yang ditimbulkan pada peserta didik secara personal akibat aplikasi metode pembelajaran (2soal);

5. Tingkat kebermaknaan aktivitas pembelajaran yang telah ditimbulkan dalam diri peserta didik akibat pembelajaran yang dilaksanakan (2soal);

6. Tingkat pemahaman konsep meliputi mengenali, menjelaskan, dan menginterpretasi yang ditimbulkan dalam diri peserta didik akibat pembelajaran yang dilaksanakan (6soal);

7. Tingkat keberlanjutan (kontinuitas) metode pembelajaran yang digunakan untuk pembelajaran materi fisika yang lain (2soal);
8. Tingkat penerimaan peserta didik terhadap pemakaian bilingual (dwibahasa) dalam pembelajaran yang dilakukan (2soal);

9. Tingkat penerimaan peserta didik terhadap pengkondisian atau penjelasan oleh dosen dalam pembelajaran (2soal); dan

10. Tingkat penerimaan peserta didik terhadap pembahasan-pembahasan soal yang dilaksanakan dalam pembelajaran (2soal).

Model pembelajaran penelitian merupakan deskripsi komprehensif terhadap interaksi antara dosen dengan mahasiswa selama melaksanakan pembelajaran di kelas. Model pembelajaran juga memberi gambaran utuh perihal efektivitas pemakaian waktu untuk kapasitas materi pembelajaran yang disajikan dalam rangka mencapai tujuan pembelajaran. Dalam penelitian ini, model pembelajaran terdiri atas 3 tahapan kegiatan utama, yaitu:

1. Pendahuluan meliputi penjelasan tujuan pembelajaran yang akan dicapai, pembagian dokumen bahan ajar dan dokumen urutan konsep materi getaran terkait. Alokasi waktu \pm 15 menit.

2. Kegiatan inti meliputi: tahap 1 berupa penjelasan urutan konsep dalam materi untuk pengkondisian kognitif mahasiswa, sebelum materi disampaikan melalui video pembelajaran; tahap 2 berupa penayangan video perdana materi terkait; tahap 3 berupa diskusi perihal penjelasan materi terkait dari dosen berbasis pertanyaan mahasiswa dan isi materi video pembelajaran perdana; tahap 4 berupa penayangan video pembelajaran kedua yang memuat materi getaran lanjutan; tahap 5 berupa diskusi perihal penjelasan materi terkait dari dosen berbasis pertanyaan mahasiswa dan isi materi video pembelajaran kedua; demikian seterusnya. Alokasi waktu menyesuaikan dengan kapasitas materi getaran terkait, yang ada dalam getaran harmonis, teredam, dan terpaksa. Alokasi waktu dibatasi \pm 70 menit.

3. Penutup dimana dosen menyimpulkan karakter tiap konsep yang ada dalam sub pokok bahasan getaran berbasis setiap tujuan pembelajaran khusus yang telah ditetapkan. Alokasi waktu \pm 15 menit.

Tiap sub pokok bahasan getaran dialokasikan $1 x$ pertemuan dengan jumlah waktu \pm 100 menit. Dengan demikian untuk seluruh sub pokok bahasan membutuhkan $3 x$ pertemuan, masing-masing \pm 100 menit. 
Rekapitulasi hasil pengembangan objek penelitian dan instrumen penelitian pendukung kepada pakar ditunjukkan pada Tabel 1. Terhadap setiap tipe instrumen, pakar tampak memberikan penilaian B baik untuk katagori DLK maupun KK. Walaupun demikian, ada 1 saran perihal model pembelajaran penelitian, khususnya pada bagian kegiatan inti yang dilaksanakan dalam tahap pembelajaran. Disini tampak bahwa revisi hanya menyangkut masalah penyempurnaan kegiatan inti dari model pembelajaran penelitian. Berdasarkan saran pakar ini tampak kegiatan inti dari model pembelajaran penelitian menjadi lebih efektif ketika mahasiswa melaksanakan kegiatan pemahaman konsep getaran terkait. Tipe-tipe instrumen penelitian yang lain sudah bernilai B baik dalam katagori DLK maupun katagori KK sehinggga komponen-komponen dan sub-sub komponen ini tidak perlu direvisi lagi. Saran ini diperhatikan sebagai bahan revisi bagi model pembelajaran penelitian dan hasil revisinya untuk selanjutnya digunakan pada kegiatan ujicoba model pembelajaran penelitian.

Tabel 1 Penilaaian pakar metode pembelajaran

\begin{tabular}{|c|c|c|c|}
\hline & Tine & DLK & KK \\
\hline No & 11ре & B $\mathrm{S}$ & B $\mathrm{S}$ \\
\hline 1. & $\begin{array}{l}\text { Bahan ajar pokok bahasan } \\
\text { getaran }\end{array}$ & $\mathrm{V}$ & $\mathrm{v}$ \\
\hline 2. & $\begin{array}{l}\text { Urutan konsep materi } \\
\text { getaran }\end{array}$ & V & $\mathrm{v}$ \\
\hline 3. & Analisis konsep getaran & $\mathrm{v}$ & $\mathrm{v}$ \\
\hline 4. & $\begin{array}{lr}\text { Analisis } & \text { indikator } \\
\text { pemahaman } & \text { konsep } \\
\text { getaran } & \end{array}$ & $\mathrm{V}$ & $\mathrm{v}$ \\
\hline 5. & $\begin{array}{l}\text { Kisi dan soal pemahaman } \\
\text { konsep getaran }\end{array}$ & V & $\mathrm{V}$ \\
\hline 6. & $\begin{array}{l}\text { Kisi dan soal angket } \\
\text { penilaian mahasiswa } \\
\text { perihal kelayakan model } \\
\text { pembelajaran penelitian }\end{array}$ & $\mathrm{V}$ & $\mathrm{V}$ \\
\hline 7. & $\begin{array}{l}\text { Model pembelajaran } \\
\text { getaran berbasis video } \\
\text { youtube }\end{array}$ & $\mathrm{V}$ & $\mathrm{V}$ \\
\hline
\end{tabular}

Saran:

Terhadap tipe instrumen model pembelajaran sebaiknya kegiatan inti yaitu diskusi setelah ada penayangan video materi terkait, diganti dengan diskusi yang disisipkan selama penayangan video sehingga kegiatannya lebih efektif dan kegiatan disesuaikan dengan kebutuhan atau ada tidaknya pertanyaan yang diajukan oleh mahasiswa terkait konten materi yang ada dalam penayangan video terkait.

Keterangan:
DLK: Dalam Linkup Konsep

KK : Kebenaran Konsep,

B : Benar, dan

$\mathrm{S}$ : Salah.

Pengembangan lain melalui ujicoba terbatas I model pembelajaran pada mahasiswa kelas eksperimen tanpa memakai kelas kontrol. Kegiatan diawali dengan tes awal, dilanjutkan penerapan model pembelajaran penelitian, lalu tes akhir dan diakhiri dengan pengisian angket penilaian oleh 24 mahasiswa. Instrumen soal untuk mengukur pemahaman konsep hanya memakai 20 soal getaran harmonis sebagai sampling dari 45 soal keseluruhan. Sampling soal pemahaman konsep meliputi 15 soal tipe PG dan 5 soal tipe uraian. Dalam penelitian ini, soal pemahaman konsep getaran teredam dan getaran terpaksa tidak dipakai karena sub-sub pokok bahasan ini termasuk "tidak wajib" sesuai tuntutan silabus-kurikulum tempat penelitian, khususnya prodi DE di POLMAN Bandung dan prodi AE di POLBAN Bandung. Alasan lain adalah sub-sub pokok bahasan ini sarat dengan penerapan Hukum II Newton berbasis keterampilan matematika tingkat tinggi, yaitu kalkulus perihal: "penyelesaian masalah persamaan differensial orde 2 ".

Tampak bahwa perolehan capaian skor rerata tes awal, tes akhir, dan NG pemahaman konsep getaran oleh mahasiswa kelas ujicoba terbatas I terkait dengan penerapan model pembelajaran penelitian, masing-masing adalah sebesar 28.2, 34.6, dan 9\%. Peningkatan skor rerata pemahaman konsep mahasiswa dari tes awal ke tes akhir, tergolong sangat rendah (Meltzer, 2002). Fakta ini didukung dari hasil uji statistika dimana perolehan skor rerata tes akhir tidak berbeda secara signifikan dengan skor rerata tes awal atau peningkatan pemahaman konsep getaran mahasiswa kelas ujicoba terbatas I tidak ada perbedaan secara signifikan.

Rekapitulasi hasil penilaian mahasiswa kelas ujicoba terbatas I setelah mengikuti tes awal, penerapan model pembelajaran penelitian, dan tes akhir ditunjukkan oleh Tabel 2. Rerata skor tanggapan tertinggi terjadi pada "tingkat motivasi diri yang ditimbulkan pada peserta didik secara personal akibat aplikasi metode pembelajaran" dan "tingkat penerimaan peserta didik terhadap pembahasan-pembahasan soal yang dilakukan dalam pembelajaran". Peringkat tertinggi ke-2 terjadi pada "tingkat kuriositas (minat dan rasa ingin tahu) peserta didik yang ditimbulkan oleh metode 
pembelajaran" dan "tingkat penerimaan peserta didik terhadap pengkondisian atau penjelasan oleh dosen dalam pembelajaran".

Peringkat tertinggi ke-3 terjadi pada "tingkat kebermaknaan aktivitas pembelajaran yang telah ditimbulkan dalam diri peserta didik akibat pembelajaran yang dilaksanakan". Peringkat tertinggi ke-4 terjadi pada "tingkat penerimaan peserta didik terhadap sistimatika materi yang telah disajikan" dan "tingkat penerimaan peserta didik terhadap metode pembelajaran yang dilaksanakan”.

Tabel 2. Tanggapan kelas ujicoba terbatas I

\begin{tabular}{|c|c|c|}
\hline No & Aspek pengukuran & Rerata \\
\hline 1 & $\begin{array}{l}\text { Tingkat penerimaan peserta didik } \\
\text { terhadap sistimatika materi yang } \\
\text { telah disajikan; }\end{array}$ & 2.7 \\
\hline 2 & $\begin{array}{l}\text { Tingkat penerimaan peserta didik } \\
\text { terhadap metode pembelajaran } \\
\text { yang dilaksanakan; }\end{array}$ & 2.7 \\
\hline 3 & $\begin{array}{l}\text { Tingkat kuriositas (minat dan } \\
\text { rasa ingin tahu) peserta didik } \\
\text { yang ditimbulkan oleh metode } \\
\text { pembelajaran; }\end{array}$ & 2.9 \\
\hline 4 & $\begin{array}{l}\text { Tingkat motivasi diri yang } \\
\text { ditimbulkan pada peserta didik } \\
\text { secara personal akibat aplikasi } \\
\text { metode pembelajaran; }\end{array}$ & 3.0 \\
\hline 5 & $\begin{array}{l}\text { Tingkat kebermaknaan aktivitas } \\
\text { pembelajaran yang telah } \\
\text { ditimbulkan dalam diri peserta } \\
\text { didik akibat pembelajaran yang } \\
\text { dilaksanakan; }\end{array}$ & 2.8 \\
\hline 6 & $\begin{array}{l}\text { Tingkat pemahaman konsep } \\
\text { meliputi mengenali, menjelaskan, } \\
\text { dan menginterpretasi yang } \\
\text { ditimbulkan dalam diri peserta } \\
\text { didik akibat pembelajaran yang } \\
\text { dilaksanakan; }\end{array}$ & 2.3 \\
\hline & $\begin{array}{lr}\text { Tingkat } & \text { keberlanjutan } \\
\text { (kontinuitas) } & \text { metode }\end{array}$ & \\
\hline 7 & $\begin{array}{l}\text { pembelajaran yang digunakan } \\
\text { untuk pembelajaran materi fisika } \\
\text { yang lain. }\end{array}$ & 2.4 \\
\hline 8 & $\begin{array}{l}\text { Tingkat penerimaan peserta didik } \\
\text { terhadap pemakaian bilingual } \\
\text { (dwibahasa) dalam pembelajaran } \\
\text { yang dilakukan }\end{array}$ & 2.6 \\
\hline 9 & $\begin{array}{l}\text { Tingkat penerimaan peserta didik } \\
\text { terhadap pengkondisian atau } \\
\text { penjelasan oleh dosen dalam } \\
\text { pembelajaran; }\end{array}$ & 2.9 \\
\hline 10 & $\begin{array}{l}\text { Tingkat penerimaan peserta didik } \\
\text { terhadap }\end{array}$ & 3.0 \\
\hline & pembahasan soal yang & \\
\hline
\end{tabular}

dilaksanakan dalam

pembelajaran.

Rerata keseluruhan 2.7

Peringkat tertinggi ke-5 terjadi pada "tingkat penerimaan peserta didik terhadap pemakaian bilingual (dwibahasa) dalam pembelajaran yang dilakukan". Peringkat tertinggi ke-6 terjadi "tingkat keberlanjutan (kontinuitas) metode pembelajaran yang digunakan untuk pembelajaran materi fisika yang lain". Peringkat terakhir atau terburuk terjadi pada "tingkat pemahaman konsep meliputi mengenali, menjelaskan, dan menginterpretasi yang ditimbulkan dalam diri peserta didik akibat pembelajaran yang dilaksanakan". Skor rerata penilaian kelayakan model pembelajaran penelitian secara keseluruhan yang diberikan oleh mahasiswa adalah masih dibawah 3 skala Likert.

Rendahnya perolehan baik untuk skor rerata NG pemahaman konsep getaran maupun untuk skor rerata penilaian kelayakan model pembelajaran dalam kegiatan ujicoba terbatas I ini disebabkan oleh adanya kendala "audio" dari sepasang speaker yang digunakan dalam penayangan video pembelajaran. Hal ini menjadi rekomendasi untuk menggantikannya dengan sepasang speaker lain sehingga volume suara yang dihasilkan dapat menjangkau semua audien dan tidak mendengung seperti yang terjadi dalam kegiatan ujicoba terbatas I terhadap model pembelajaran penelitian. Setelah tahapan ini, peneliti tidak merevisi bagian-bagian dari model pembelajaran penelitian, sehingga model pembelajaran hasil revisi berbasis saran pakar, langsung digunakan lagi untuk ujicoba terbatas II.

Kegiatan ujicoba terbatas II sebagai pelaksanaan tahap validasi model pembelajaran penelitian melibatkan 30 mahasiswa dari kelas eksperimen dan 27 mahasisiwa dari kelas kontrol. Kelas kontrol adalah kelas pembanding dimana pembelajaran getaran-nya memakai metode ceramah berbasis aplikasi microsoft powerpoint presentation. Perolehan skor rerata tes awal, tes akhir, dan NG pemahaman konsep, masing-masing adalah 45.7 , 55.2, dan $14 \%$ untuk kelas kontrol dan 32.9, 61.0, dan $41 \%$ untuk kelas eksperimen.

Validasi model pembelajaran juga dilakukan dengan memakai angket penilaian mahasiswa kelas eksperimen perihal kelayakannya. Rekapitulasi hasil validasinya ditunjukkan pada Tabel 3. Dengan instrumen serupa seperti pada ujicoba terbatas I tampak 
bahwa skor paling rendah terjadi pada "tingkat penerimaan peserta didik terhadap pemakaian bilingual (dwibahasa) dalam pembelajaran yang dilakukan". Pembelajaran dengan konten bilingual tampak kontra produktif terhadap tujuan pembelajaran terkait.

Tabel 3 Penilaian Kelas Eksperimen

\begin{tabular}{|c|c|c|}
\hline No & Aspek pengukuran & Rata2x \\
\hline 1 & $\begin{array}{l}\text { Tingkat penerimaan peserta } \\
\text { didik terhadap sistimatika materi } \\
\text { yang telah disajikan; }\end{array}$ & 3.2 \\
\hline 2 & $\begin{array}{llr}\text { Tingkat penerimaan } & \text { peserta } \\
\text { didik } & \text { terhadap } & \text { metode } \\
\text { pembelajaran } & \text { yang } \\
\text { dilaksanakan; } & \end{array}$ & 3.3 \\
\hline 3 & $\begin{array}{l}\text { Tingkat kuriositas (minat dan } \\
\text { rasa ingin tahu) peserta didik } \\
\text { yang ditimbulkan oleh metode } \\
\text { pembelajaran; }\end{array}$ & 3.3 \\
\hline 4 & $\begin{array}{l}\text { Tingkat motivasi diri yang } \\
\text { ditimbulkan pada peserta didik } \\
\text { secara personal akibat aplikasi } \\
\text { metode pembelajaran; }\end{array}$ & 3.3 \\
\hline 5 & $\begin{array}{l}\text { Tingkat kebermaknaan aktivitas } \\
\text { pembelajaran yang telah } \\
\text { ditimbulkan dalam diri peserta } \\
\text { didik akibat pembelajaran yang } \\
\text { dilaksanakan; }\end{array}$ & 3.3 \\
\hline 6 & $\begin{array}{lr}\text { Tingkat pemahaman } & \text { konsep } \\
\text { meliputi } & \text { mengenali, } \\
\text { menjelaskan, } & \text { dan } \\
\text { menginterpretasi } & \text { yang } \\
\text { ditimbulkan dalam diri peserta } \\
\text { didik akibat pembelajaran yang } \\
\text { dilaksanakan; }\end{array}$ & 2.9 \\
\hline 7 & $\begin{array}{l}\text { Tingkat keberlanjutan } \\
\text { (kontinuitas) metode } \\
\text { pembelajaran yang digunakan } \\
\text { untuk pembelajaran materi fisika } \\
\text { yang lain. }\end{array}$ & 3.2 \\
\hline 8 & $\begin{array}{l}\text { Tingkat penerimaan peserta } \\
\text { didik terhadap pemakaian } \\
\text { bilingual (dwibahasa) dalam } \\
\text { pembelajaran yang dilakukan }\end{array}$ & 2.7 \\
\hline 9 & $\begin{array}{l}\text { Tingkat penerimaan peserta } \\
\text { didik terhadap pengkondisian } \\
\text { atau penjelasan oleh dosen } \\
\text { dalam pembelajaran; }\end{array}$ & 3.5 \\
\hline 10 & $\begin{array}{lrr}\text { Tingkat penerimaan peserta } \\
\text { didik terhadap pembahasan- } \\
\text { pembahasan } & \text { soal } & \text { yang } \\
\text { dilaksanakan } & & \text { dalam } \\
\text { pembelajaran. } & & \\
\end{array}$ & 3.4 \\
\hline & Rerata keseluruhan: & 3.2 \\
\hline
\end{tabular}

Persepsi terendah ke-2 terjadi pada "tingkat pemahaman konsep meliputi mengenali, menjelaskan, dan menginterpretasi konsep yang ditimbulkan dalam diri peserta didik akibat pembelajaran yang dilaksanakan.". Dua katagori terendah ini menjadi feedback atau rekomendasi untuk mendapat perhatian ketika melakukan pengembangan model pembelajaran selanjutnya.

Untuk katagori lainnya tampak kelas eksperimen memberi penilaian dengan indeks rerata diatas 3.0 skala Likert dengan indeks rerata tertinggi terjadi pada "tingkat penerimaan peserta didik terhadap pengkondisian atau penjelasan oleh dosen dalam pembelajaran". Secara keseluruhan rerata indeks penilaian kelas eksperimen sudah diatas 3.0 skala Likert.

Hasil tahap validasi menunjukkan bahwa: (i) ke-2 kelas mengalami peningkatan skor rerata dari tes awal ke tes akhir; (ii) skor rerata NG kelas eksperimen lebih tinggi dari kelas kontrol, katagori sedang untuk kelas ekperimen, katagori rendah untuk kelas kontrol (Meltzer, 2002); (iii) skor rerata NG kelas eksperimen berbeda signifikan dengan kelas kontrol berbasis hasil uji statistika; (iv) model pembelajaran penelitian termasuk "sudah layak digunakan menurut sebagian mahasiswa", bahkan "sudah sangat layak digunakan menurut sebagian mahasiswa lainnya"; (v) katagori kelayakan model pembelajaran penelitian termasuk diantara "sudah baik" dan "sangat baik". Hasil tahap ini dapat dimaknai bahwa pengembangan model pembelajaran yang dilakukan sudah on the track atau berada pada arah pengembangan yang benar dan penerapan model pembelajaran di lapangan sudah memuat kekhasan-kekhasan yang melekat, seperti telah dipaparkan pada bagian pendahuluan paper ini. Dengan demikian pembelajaran fisika dasar di PT dapat memanfaatkan video pembelajaran dari website http://youtube.com sebagai solusi alternatif dalam memberi layanan pendidikan fisika terbaik bagi mahasiswa.

Kekuatan dan kelemahan model pembelajaran penelitian dianalisis dari hasil pengamatan yang dilakukan selama proses penelitian berjalan, terutama dari data ujicoba terbatas I dan II. Kekuatan model pembelajaran, antara lain:

1. Video-video pembelajaran yang digunakan untuk 1 sub pokok bahasan merupakan hasil kolaborasi beberapa kreator. Pelayanan untuk 1 sub pokok bahasan telah memuat konsep-konsep yang sangat komprehensif sehingga mahasiswa dapat 
mempelajari konsep getaran secara utuh tanpa ada bagian yang hilang. Disisi lain video dengan kreator berbeda juga menampilkan variasi metode mengajar khas setiap kreator Metode mengajar pilihan terbaik mampu meningkatkan motivasi belajar peserta didik (Widyaningtyas, 2013). Pembelajaran fisika efektif dan efisien dapat diciptakan, salah satunya melalui metode bervariasi (Susanti, 2016).

2. Konten pembelajaran dapat diakses kapanpun dan dimanapun oleh mahasiswa karena dengan mudah dapat dilihat dan diunduh dari internet sehingga bisa menjadi dokumen pribadi mahasiswa. Sekiranya ada mahasiswa yang belum memahami konsepkonsep yang diajarkan dalam perkuliahan tatap muka maka mahasiswa tersebut dapat mengulang pembelajaran kembali di rumah atau di tempat lain, baik secara individu maupun berkelompok. Pengulangan akan memperkuat pemahaman konsep peserta didik (Mahardika, 2012).

3. Bagi dosen selaku fasilitator dapat menghemat tenaga dalam memberi layanan perkuliahan tatap muka. Dosen dapat meminimalisasi penjelasan konsep-kosep yang pada umumnya disampaikan secara panjang lebar. Tenaga sisa dosen setelah menyelenggarakan perkuliahan tatap muka dengan metode ini dapat diarahkan pada persiapan kegiatan evaluasi yang mendidik dan bermakna bagi perkembangan studi lebih lanjut dari setiap mahasiswa yang bersangkutan. Bahkan terjadi $\pm 40 \%$ penghematan waktu penyampaian konsep dan bisa untuk menambah presentasi verbalnya (Zaenal, 2012).

4. Jumlah video pembelajaran youtube yang memuat konten sub-sub pokok bahasan serupa dapat ditemukan dalam jumlah cukup banyak. Keadaan ini memberi kesempatan seluas-luasnya bagi mahasiswa yang bermotivasi tinggi dalam mempelajari sub pokok bahasan tertentu dalam rangka memperoleh penguatan konsep yang sulit. Dengan demikian kedalaman pemahaman konten sub-sub pokok bahasan yang dipelajari mahasiswa dapat dijamin sehingga setiap tujuan pembelajaran dapat diwujudkan. Pencapaian 100\% tujuan pembelajaran dari setiap sub pokok bahasan sangat terkait dengan skema pembelajaran tuntas dan bermakna. Skema ini termasuk pembelajaran aktif bagi peserta didik yang mampu menghilangkan persepsi sulit suatu mata pelajaran, seperti matematika, fisika dan sejenisnya (Gazali, 2016).

Kelemahan model pembelajaran, antara lain:

1. Video-video pembelajaran untuk 1 sub pokok bahasan tidak dapat ditemukan dalam satu file, melainkan harus menggunakan beberapa file dari beberapa kreator. Durasi waktu penayangan video pembelajaran dari youtube.com juga relatif singkat, ada dibawah 10 menit biasanya untuk produk lokal dan diatas 10 menit biasanya untuk produk asing. Ini menyulitkan mahasiswa dalam mempelajari pokok-pokok bahasan yang ada dalam mata kuliah fisika. Mahasiswa harus mempunyai keterampilan dalam melakukan searching video pembelajaran untuk 1 sub pokok bahasan yang dikehendaki.

2. Video-video pembelajaran untuk pokok bahasan fisika mayoritas masih berasal dari produk asing, sehingga memakai bahasa asing (English). Untuk sub-sub pokok bahasan dengan level kesulitan diatas standar tampak tidak ada yang berbahasa Indonesia. Ini menjadi kendala besar bagi pemakaian model pembelajaran ini dan kendala ini dapat diatasi jika video pembelajaran tersebut dapat diproduksi sendiri oleh dosen atau guru atau pengajar yang terlibat langsung dalam pengajaran.

3. Ada ketidak-bebasan dari dosen selaku pengajar dalam memberikan pelayanan perkuliahan kepada mahasiswa. Dosen sangat terikat dengan desain konsep-konsep fisika yang ada dalam video pembelajaran sehingga dosen harus mengadaptasi skenario pembelajaran, khususnya dalam kegiatan inti model pembelajaran. Ini berdampak kepada tujuan pembelajaran khusus yang disusun dosen, dimana dosen harus menyesuaikan tujuan pembelajaran dengan konten video pembelajaran youtube yang digunakan. Ini memberikan peluang kepada dosen untuk dapat membuat dan mengembangkan video pembelajaran sendiri karena sesuai hasil penelitian yang didapat tampak pmbelajaran getaran berbasis video youtube berdampak lebih signifikan dibanding metode pembelajaran ceramah berbasis ppt.

\section{Simpulan dan Saran}

Simpulan

Dari hasil temuan dan pembahasan diatas dapat ditarik beberapa simpulan, antara lain: 
1. Model pembelajaran getaran berbasis video youtube untuk meningkatkan pemahaman konsep terdiri atas: (i) Pendahuluan meliputi penjelasan tujuan pembelajaran dan pembagian dokumen bahan ajar pokok bahasan getaran serta dokumen urutan materi getaran. Alokasi waktu \pm 15 menit; (ii) Kegiatan inti meliputi pengkondisian awal melalui penjelasan urutan materi getaran dan penayangan beberapa video pembelajaran youtube yang terkait dengan 1 sub pokok bahasan, serta diselingi diskusi/tanya-jawab jika ada inisiasi dari mahasiswa dan, atau dosen jika diperlukan. Alokasi waktu \pm 70 menit; (iii) penutup meliputi dosen meresume simpulan konsepkonsep yang terkait dengan tujuan pembelajaran. Alokasi waktu \pm 15 menit.

2. Katagori kelayakan model pembelajaran getaran berbasis video-youtube yang dinilai pakar sudah benar baik dalam katagori "dalam lingkup konsep" maupun dalam katagori "kebenarn konsep".

3. Katagori kelayakan model pembelajaran getaran berbasis video-youtube yang dinilai oleh mahasiswa kelas eksperimen tanpa memakai kelas kontrol sudah diatas cukup baik namun masih dibawah baik. Sedangkan penilaian oleh mahasiswa kelas eksperimen yang memakai kelas kontrol, sudah diatas baik namun masih dibawah sangat baik.

4. Model pembelajaran memuat konsep yang komprehensif, mudah diakses jika ada pengulangan, hemat tenaga bagi dosen dalam menjelaskan, dan resource untuk 1 sub pokok bahasan dapat dari beberapa video beragam dengan kreator berbeda;

5. Video-video yang digunakan dalam pembelajaran 1 sub pokok bahasan masih berupa kompilasi beberapa file, resource yang berbahasa Indonesia terbatas, memuat konten dengan tujuan pembelajaran yang bersifat mengikat sehingga perlu penyesuaian dengan tuntutan kurikulum yang berlaku.

Saran

Untuk meningkatkan kualitas model pembelajaran getaran berbasis video-youtube maka perlu dilakukan pengkondisian antara lain:

1. Satu video pembelajaran dibuat hanya untuk 1 sub pokok bahasan ;

2. Video pembelajaran dapat dibuatkan dalam bahasa Indonesia, dan lebih baik lagi berbahasa daerah lokal untuk level pendidikan menengah dan dasar; dan

3. Konten video pembelajaran agar selalu diselaraskan dengan tujuan pembelajaran sesuai kurikulum, khususnya sub-pokok bahasan terkait.

\section{Ucapan Terima Kasih}

Terima kasih kepada institusi Politeknik Negeri Bandung, prihal pendanaan yang telah diberikan untuk pembiayaan penelitian internal ini.

\section{Daftar Pustaka}

Al-Tabany, T. I. B. (2017). Mendesain Model Pembelajaran Inovatif Progresif, dan Kontekstual. (Cetakanke3). Jakarta: PT Kharisma Putra Utama.

Basuki, R. (2017). Studi kasus: konsep penentuan bilangan oksidasi pada buku paket kimia SMA/MA di Indonesia. Jurnal Pendidikan Sains (JPS), 5(2), 71-79.

Burgess, J. \& Green, J. (2018). YouTube: Online Video and Participatory Culture. (2 $\left.{ }^{\text {th }} e d.\right)$. Cambridge: Polity Press.

Dahar, R. W. (2011). Teori - Teori Belajar dan Pembelajaran. Bandung: Erlangga.

Falahudin, I. (2014). Pemanfaatan media dalam pembelajaran. Jurnal Lingkar Widyaiswara (JLW), 1(4), 104-117.

Gazali, R.Y. (2016). Pembelajaran Matematika Yang Bermakna. Math Didactic: Jurnal Pendidikan Matematika, 2(3), 181-190.

Giancoli, D. C. (2016). Physics: Principles with Applications. (global-ed.). Boston: Pearson Education Limited.

Hidayat, S., Supriadin, \& Iskandar, J. (2018). Pengembangan prototipe buku ajar terintegrasi proses saintifik untuk meningkatkan keterampilan berpikir kritis siswa. Konstan: Jurnal Fisika dan Pendidikan Fisika, 3(1), 36-47.

Izzudin, A. M., Masugino, \& Suharmanto, A. (2013). Efektivitas penggunaan media pembelajaran video interaktif untuk meningkatkan hasil belajar praktik service engine dan komponenkomponennya. Automotive Science and Education Journal, 2(2):1-8. 
Mahardika, I K. (2012). Representasi Mekanika Dalam Pembahasan: Sebuah Teori dan Hasil Penelitian Pengembangan Bahan Ajar Mekanika, ( ${ }^{\text {th }}$ ed.). Jember: UPT Penerbitan Universitas Negeri Jember.

Meltzer, D. E. (2002). The relationship between mathematics preparation and conceptual learning gains in physics: A possible "hidden variable" in diagnostic pretest scores. American Journal of Physics, 70, 1259-1268.

Munadi, Y. (2013). Media pembelajaran sebuah pendekatan baru. Jakarta: Gaung Persada Press.

Mustari, M. \& Rahman, M.T. (2014). Manajemen pendidikan. Jakarta: PT RajaGrafika Persada.

Nopiani, R., Harjono, A., \& Hikmawati. (2017). Jurnal Pendidikan Fisika dan Teknologi, 3(2), 137-145.

Nurjamilah, Sulaeman, N.F., \& Komariyah, L. (2017). Penggunaan instrumen ordered multiple choice (OMC) untuk menilai pemahaman konsep usaha dan energi dengan model pembelajaran discovery di SMAN 1 Long Kali. Berkala Ilmiah Pendidikan Fisika, 5(3), 241-253.

Priyadi, R., Diantoro, M. \& Parno. (2018). Kajian literatur: model mental dan metode evaluasinya. Jurnal Pendidikan Sains (JPS), 6(2), 70-75.

Purwanti, B. (2015). Pengembangan media video pembelajaran matematika dengan model assure. Jurnal Kebijakan dan Pengembangan Pendidikan, 3(1), 4247.

Rasagama, I G. (2011). Memahami implementasi "educational research and development". Makalah Disampaikan dalam Kegiatan Pelatihan Metodologi Penelitian Kuantitatif Untuk Dosen UPMKU dan Unit Lainnya, di Politeknik Negeri Bandung, tanggal 16 Agustus 2011, diunduh dari http://digilib.polban.ac.id/files/disk1/65 /jbptppolban-gdl-igederasag-3209-1memahami-\%E2\%80\%9D.pdf.

Bandung: Politeknik Negeri Bandung.

Sariningsih, R. (2014). Pendekatan kontekstual untuk meningkatkan kemampuan pemahaman matematis siswa SMP. Infinity: Jurnal Ilmiah Program Studi Matematika STKIP Siliwangi Bandung, 3(2), 150-163.

Susanti, F., Ayub, S., \& Taufik, M. (2016). Perbedaan hasil belajar fisika melalui model pembelajaran kooperatif tipe numbered heads together (nht) berbantuan kartu soal dengan model pembelajaran direct instruction di SMAN 7 Mataram. Jurnal Pendidikan Fisika dan Teknologi. 2(4), 147-153.

Triwiyanto, T. (2013). Standar nasional pendidikan sebagai indikator mutu layanan manajemen sekolah. Jurnal Ilmu Pendidikan, 19(2), 161-171.

Widyaningtyas, A. (2012). Peran lingkungan belajar dan kesiapan belajar terhadap prestasi belajar fisika siswa kelas $\mathrm{X}$ Sekolah Menengah Atas Negeri 1 Pati. Skripsi, diunduh dari https://digilib.uns.ac.id/dokumen/detail/ 30353. Universitas Sebelas Maret Surakarta.

Young, H.D., \& Freedman, R.A. (2016). University Physics with Modern Physics. (14 $4^{\text {th }}$ ed.). Boston: Pearson Education Limited.

Yuliyanto, E., Hidayah, F.F., Istyastono, E.P., \& Wijoyo, Y. (2018). Refleksi praktikum kimia organik calon pendidik kimia menggunakan rekaman video. Jurnal Pendidikan Sains (JPS), 5(2), 76-83.

Zaenal, A. (2012). Pengembangan Media Video Pembelajaran IPA tentang Kemagnetan pada kelas IX SMPN Mojowarno Jombang. Tesis, tidak dipublikasikan. Universitas Negeri Malang. 